\title{
A Local Stability of Mathematical Models for Cancer Treatment by Using Gene Therapy
}

\author{
Dwi Lestari and Ratnasari Dwi Ambarwati
}

\begin{abstract}
This study observed a local stability of mathematical model for cancer treatment by using gene therapy. Started with modelling the Gene Therapy for Cancer Treatment then continued with the discussion about equilibrium point, the model was developed by Lotka-Volterra model. It is very important to investigate the behaviour of equilibrium point such as the stability of that point in certain conditions especially a local stability. Furthermore, simulation of the model was given by taking some certain parameter values.
\end{abstract}

Index Terms-Cancer, gene therapy, Lotka Volterra, stability.

\section{INTRODUCTION}

Cancer is a worldwide major cause of death. Cancer arises as a result of the rapid and uncontrollable growth of abnormal cells in the human body. Cell is the smallest part of the body and cancer occurs from normal cells. Some types of cancers include breast cancer, cervical cancer, brain cancer, lung cancer, and bone cancer. Cancer is caused by chemical substances, alcoholic beverages, excessive solar radiation, genetic differences, and so on [1]. Various methods are used to cure or inhibit the growth of cancer. The type of treatment, such as surgery, radiation therapy, chemotherapy, target therapy, immunotherapy, hormonal therapy, angiogenesis inhibitors, palliative care, and the last is a gene therapy. Each therapy has side effects, eg nausea, vomiting, pressing the blood production, fatigue, hair loss and mouth sores. Side effects occur, as a result of chemotherapy drugs not only kill cancer cells but also normal cells that divide rapidly. Such as, cell gastrointestinal tract, skin, hair and sperm [2]. Therefore, other therapies developed for the treatment of cancers such as gene therapy.

The latest treatment methods are still in the research stage is gene therapy. Treatment of cancer undergoes evolutionary change as the understanding of the biological processes that underlie the occurrence of cancer. Surgical removal of the tumor has been documented in ancient Egypt, hormone therapy was developed in 1896 , and radiation therapy was developed in 1899. Chemotherapy, immunotherapy, and new targeted therapies are a product of the 20th century. A new treatment needs to be developed and modified to improve the effectiveness, high precision, as well as the size of survival skills, and improve the quality life of patients. One of the

Manuscript received December 13, 2014; revised March 3, 2015. This work was supported in part by Internasional affairs and partnerships Yogyakarta State University Indonesia.

The authors are with the Department of Mathematics Education, Faculty of Mathematics and natural Science, Yogyakarta State University, Indonesia (e-mail: dwilestari@uny.ac.id, dwilestari.math@gmail.com, naasaa28@gmail.com ). therapies that are expected to be the future solution is Gene Therapy. This therapy will specifically against cancer cells, specific area, without disturbing normal cells in the body [3]

Cancer is a genetic alteration so that the gene therapy methods to be one type of treatment against cancer. Genetic changes could lead to cell cycle regulation. In normal cells there is a balance between cell proliferation with cell death which is regulated through the cell cycle with cellular checkpoint. One of the characteristics of cancer cells is the loss of checkpoint control [4]. Gene therapies performed by replacing or inactivate genes that do not work, adding a functional gene, or insert a gene into the cells to make the normal functioning of cells [5]. In contrast to the method of immunotherapy treatment that refers to the use of cytokines, namely interleukin-2 (IL-2), the method of gene therapy, IL-2 eliminated from the immunotherapy model and replaced by self-proliferation that is $p_{1} \frac{E}{E+f}[1]$.

The process of gene therapy that has the characteristics of controlling the speed of cancer cells growth is particular interest. Seen from the mathematics point of view, gene therapy for cancer can be modelled mathematically in the form of differential equations systems. Based on the Lotka-Volterra model, in 1994 Kuznetsov developed the Lotka-Volterra model in 1994. Furthermore in 1998 [6], Kirschner and Panneta continued to build KP models developed from the Kuznetsov model by adding a cytokines population as intercellular communication molecules by the immune system. Gene therapy models developed from the two previous models made the T-cells induce every cell to produced T-cell receptor (TCR). These cells are transferred back to the cancer patient's body and will recognize and resist molecules found as tumor cells. TCR will activate T-cells that then attack and kill cancer cells. Gene therapy models are built based on the KP models.

This study focused on the growth dynamics of effector cells and tumor cells because of the influence of the use of gene therapy. These conditions can be modeled in the form of a mathematical equation. The interaction between effector cells and tumor cells is described as a competition between the two populations, therefore the interaction established mathematical models based on the system of the predator prey. The plot starts from the formation of the model, determined the equilibrium point, analyze the local stability and then simulate the model.

\section{MAthematical Model For THE SPREAd OF CANCER}

In gene therapy treatment, there are two methods in the insertion of the cell, namely the insertion of in-vivo and 
ex-vivo insertion. In-vivo insertion is the direct insertion of the vector into the target area in the body, while the ex-vivo insertion is targeted cells released from the patient's body, forced to imitate and in transduction with vectors before being returned to the patient [7]. The treatments process with gene therapy describe below:

1) Replace missing or mutated gene with a healthy gene.

2) Inserting genes into tumor that acts like suicide bombing after activated by drugs.

3) Inserting genes that make tumors more vulnerable to treatment such as chemotherapy and radiotherapy.

4) Augment the immune response to cancer by increasing the ability of immune cells, such as T cells and dendritic cells, to fight cancer cells.

The model developed by Kirschner and Panneta in 1998 [6] known as KP models shown below:

$$
\begin{gathered}
E=c T-\mu_{2} E+p_{1} \frac{E C}{g_{1}+C}+S_{1} \\
T=c T-\mu_{2} E+p_{1} \frac{E C}{g_{1}+C}+S_{1} \\
C=\frac{p_{2} E T}{g_{3}+T}+S_{2}-\mu_{3} C
\end{gathered}
$$

The notation used is

$$
\begin{array}{ll}
E(t) & : \text { effector immune cell } \\
T(t) & : \text { cancer cell } \\
C(t) & : \text { effector molecules } \\
C & : \text { antigen parameters } \\
\mu_{2} & : \text { pure death parameters } \\
S_{1} & : \text { immunotheraphy parameters }
\end{array}
$$

Equation (1b) shows the logistic growth of cancer cells, with $b^{-1}$ as a maximum capacity limit (maximum carrying capacity). Furthermore, gene therapy models obtained by removing the equation (1c) and replace it with cell proliferation (self proliferation) in equation (1a).

TABLE I: PARAMETER VALUE

\begin{tabular}{|c|l|c|c|}
\hline $\begin{array}{c}\text { Para } \\
\text { meter }\end{array}$ & Definition & Baseline & Interval \\
\hline$\mu_{2}$ & Half-life of effector cells & $\begin{array}{c}0.03 \\
(1 / \text { time })\end{array}$ & 0.03 \\
\hline$p_{3}$ & $\begin{array}{l}\text { The rate of effector cells } \\
\text { proliferation }\end{array}$ & $\begin{array}{c}0.1245 \\
(1 / \text { time })\end{array}$ & 0.1245 \\
\hline$f$ & $\begin{array}{l}\text { Half-saturation for effector } \\
\text { cell proliferation parameters }\end{array}$ & $\begin{array}{c}10^{-3}(\text { cells }) \\
{\left[10^{-5}, 1\right]}\end{array}$ \\
\hline$s_{1}(t)$ & Treatment Parameters & $\begin{array}{c}1 \\
(\text { cell/time })\end{array}$ & {$\left[10^{-2}, 10^{2}\right]$} \\
\hline$c(t)$ & Antigenicity & $\begin{array}{c}0.05 \\
(1 / \text { time })\end{array}$ & {$\left[10^{-3}, 0.5\right]$} \\
\hline$r_{2}(t)$ & The rate of tumor growth & $\begin{array}{c}0.18 \\
(1 / \text { time })\end{array}$ & {$\left[10^{-1}, 2\right]$} \\
\hline$b$ & The capacity of tumor cells & $\begin{array}{c}10^{-9}(1 \\
/ \text { cells })\end{array}$ & $10^{-9}$ \\
\hline$a(t)$ & Cancer cleanup parameters & $1(1 /$ cells $)$ & {$\left[10^{-2}, 10^{2}\right]$} \\
\hline$g_{2}$ & $\begin{array}{l}\text { Half-saturation for the cancer } \\
\text { cleaning }\end{array}$ & $\begin{array}{c}10^{5}(\text { cells }) \\
10^{5}\end{array}$ \\
\hline
\end{tabular}

Here are the assumptions required to obtain mathematical models:
1) Tumor cell growth following the logistics growth

2) Natural death occurred on effector cells

3) The population is not constant

In the literature [1] defined the values of the parameters are largely based on previous research (see Table I). These parameters are as follows:

The Transfer diagram can be seen as follow:

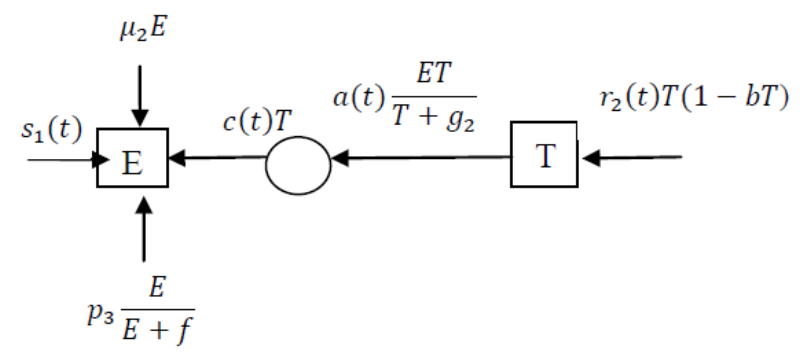

Fig. 1. Gene therapy transfer diagram model.

Based on Fig. 1, the gene therapy model developed in the form of differential equations systems is written as follows:

$$
\begin{aligned}
& \frac{d E}{d t}=c T-\mu_{2} E+p_{3} \frac{E}{E+f}+s_{1} \\
& \frac{d T}{d t}=r_{2} T(1-b T)-a \frac{E T}{T+g_{2}}
\end{aligned}
$$

with $c, s_{1}, r_{2}, a$ are constant. Where $s_{1}, a, r_{2}, g_{2},>0$ and $0<\mu_{2}, p_{3}, f, b, c \leq 1$.

\section{EQUILIBRIUM POINT}

Equation (2) will reach equilibrium point on $\frac{d E}{d t}=0$ and $\frac{d T}{d t}=0$, so the equation can be written as follows:

$$
\begin{aligned}
c T-\mu_{2} E+p_{3} \frac{E}{E+f}+s_{1} & =0 \\
r_{2} T(1-b T)-a \frac{E T}{T+g_{2}} & =0
\end{aligned}
$$

From Equation (2b) we obtain:

with :

$$
\begin{gathered}
T_{1}=0 \\
T_{2}=\frac{A_{1}-\sqrt{B_{1}}}{2 r_{2} b} \\
T_{3}=\frac{A_{1}+\sqrt{B_{1}}}{2 r_{2} b}
\end{gathered}
$$

$$
\begin{gathered}
A_{1}=\left(1-b g_{2}\right) r_{2} \\
B_{1}=\left(\left(1-b g_{2}\right) r_{2}\right)^{2}-4\left(a E-r_{2} g_{2}\right) b r_{2} .
\end{gathered}
$$

Furthermore, substitution of each (3), (4), or (5) to (2a) is obtained

$$
E_{1}=\frac{A_{2}-\sqrt{B_{2}}}{2 r_{2} b} \text { and } E_{2}=\frac{A_{2}+\sqrt{B_{2}}}{2 r_{2} b}
$$

with:

$$
\begin{gathered}
A_{2}=p_{3}+s_{1}-\mu_{2} f \\
B_{2}=\left(p_{3}+s_{1}-\mu_{2} f\right)^{2}+4 \mu_{2} s_{1} f .
\end{gathered}
$$

Thus equilibrium point $P_{1}\left(E_{1}^{*}, T_{1}^{*}\right)$ and $P_{2}\left(E_{2}^{*}, T_{1}^{*}\right)$ were obtained. It is analog for other following points: 


$$
E_{3}=\frac{A_{3}-\sqrt{B_{3}}}{2 r_{2} b} \text { and } E_{4}=\frac{A_{3}+\sqrt{B_{3}}}{2 r_{2} b}
$$

with:

$$
\begin{gathered}
A_{3}=\left(A_{1}-\sqrt{B_{1}}\right) c+2 r_{2} b\left(p_{3}+s_{1}-\mu_{2} f\right) \\
B_{3}=\left(\left(A_{1}-\sqrt{B_{1}}\right) c+2 r_{2} b\left(p_{3}+s_{1}-\mu_{2} f\right)\right)^{2}+ \\
8\left(\mu_{2} r_{2} b\right)\left(\left(A_{1}-\sqrt{B_{1}}\right) c+2 s_{1} r_{2} b\right) f .
\end{gathered}
$$

Furthermore, in order to obtain the equilibrium points of $P_{3}\left(E_{3}^{*}, T_{2}^{*}\right)$ and $P_{4}\left(E_{4}^{*}, T_{2}^{*}\right)$ :

$$
E_{5}=\frac{A_{4}-\sqrt{B_{4}}}{2 r_{2} b} \text { and } E_{6}=\frac{A_{4}+\sqrt{B_{4}}}{2 r_{2} b}
$$

with:

$$
\begin{gathered}
A_{4}=\left(A_{1}+\sqrt{B_{1}}\right) c+2 r_{2} b\left(p_{3}+s_{1}-\mu_{2} f\right) \\
B_{4}=\left(\left(A_{1}+\sqrt{B_{1}}\right) c+2 r_{2} b\left(p_{3}+s_{1}-\mu_{2} f\right)\right)^{2}+ \\
8\left(\mu_{2} r_{2} b\right)\left(\left(A_{1}+\sqrt{B_{1}}\right) c+2 s_{1} r_{2} b\right) f .
\end{gathered}
$$

Thus the equilibrium points $P_{5}\left(E_{5}^{*}, T_{3}^{*}\right)$ and $P_{6}\left(E_{6}^{*}, T_{3}^{*}\right)$ were obtained.

$P_{3}, P_{4}, P_{5}$ and $P_{6}$ points known as the equilibrium points of infected cancer. Therefore, those six equilibrium points, named as:

$$
\begin{gathered}
P_{1}\left(E_{1}^{*}, T_{1}^{*}\right), P_{2}\left(E_{2}^{*}, T_{1}^{*}\right), P_{3}\left(E_{3}^{*}, T_{2}^{*}\right), P_{4}\left(E_{4}^{*}, T_{2}^{*}\right), \\
P_{5}\left(E_{5}^{*}, T_{3}^{*} \text { and } P_{6}\left(E_{6}^{*}, T_{3}^{*}\right) .\right.
\end{gathered}
$$

\section{ANALYSIS OF EQUILIBRIUM POINT STABILITY}

Equation (2) was being linearized to obtain the Jacobian matrix as follows,

$$
J=\left[\begin{array}{cc}
-\mu_{2}+\frac{p_{3} f}{(E+f)^{2}} & c \\
-\frac{a T}{T+g_{2}} & (1-2 b T) r_{2}-\frac{a g_{2} E}{\left(T+g_{2}\right)^{2}}
\end{array}\right] .
$$

1) For cancer-free equilibrium point $P_{1}\left(E_{1}^{*}, T_{1}^{*}\right)=$ $P_{1}\left(E_{1}^{*}, 0\right)$, substituted $P_{1}\left(E_{1}^{*}, 0\right)$ into Equation (6) to obtain cancer-free Jacobian matrix:

$$
J_{P_{1}}=\left[\begin{array}{cc}
-\mu_{2}+\frac{p_{3} f}{\left(E_{1}^{*}+f\right)^{2}} & c \\
0 & r_{2}-\frac{a E_{1}^{*}}{g_{2}}
\end{array}\right]
$$

The characteristic equation of (7) is:

$$
\begin{gathered}
\lambda^{2}-\left(\frac{p_{3} f}{\left(E_{1}^{*}+f\right)^{2}}-\mu_{2}+r_{2}-\frac{a E_{1}^{*}}{g_{2}}\right) \lambda+ \\
\left(\frac{p_{3} f}{\left(E_{1}^{*}+f\right)^{2}}-\mu_{2}\right)\left(r_{2}-\frac{a E_{1}^{*}}{g_{2}}\right)=0
\end{gathered}
$$

Then, equation (8) can be written as follows:

$$
\lambda^{2}-x_{1} \lambda+y_{1}
$$

with:

$$
x_{1}=\frac{p_{3} f}{\left(E_{1}^{*}+f\right)^{2}}-\mu_{2}+r_{2}-\frac{a E_{1}^{*}}{g_{2}}
$$

$$
y_{1}=\left(\frac{p_{3} f}{\left(E_{1}^{*}+f\right)^{2}}-\mu_{2}\right)\left(r_{2}-\frac{a E_{1}^{*}}{g_{2}}\right)
$$

Eigen values were obtained from equation (8) as $y_{1}$ is the determinant of $J_{P_{1}}$ matrix and $x_{1}$ is the trace of the $J_{P_{1}}$ matrix. Based on definition and theorem [8], [9],

$$
\lambda_{1,2}=\frac{x_{1} \pm \sqrt{x_{1}^{2}-4 y_{1}}}{2}
$$

a) If $y_{1}>0$ and $x_{1}^{2}-4 y_{1} \geq 0$ then the equilibrium point $P_{1}\left(E_{1}^{*}, 0\right)$ in the form of nodes, and if $x_{1}<0$ then $P_{1}\left(E_{1}^{*}, 0\right)$ asymptotically stable. If $x_{1}>0$ then $P_{1}\left(E_{1}^{*}, 0\right)$ is unstable.

b) If $y_{1}>0, x_{1}^{2}-4 y_{1}<0$ and $x_{1} \neq 0$ then the equilibrium point $P_{1}\left(E_{1}^{*}, 0\right)$ in the form of focus, and if $x_{1}<0$ then $P_{1}\left(E_{1}^{*}, 0\right)$ asymptotically stable. If $x_{1}>0$ then $P_{1}\left(E_{1}^{*}, 0\right)$ unstable.

2) The analog characteristic equation for cancer-free equilibrium point $P_{2}\left(E_{2}^{*}, T_{1}^{*}\right)=P_{2}\left(E_{2}^{*}, 0\right)$ is written bellow

$$
\begin{aligned}
& \lambda^{2}-\left(\frac{p_{3} f}{\left(E_{2}^{*}+f\right)^{2}}-\mu_{2}+r_{2}-\frac{a E_{2}^{*}}{g_{2}}\right) \lambda+ \\
& \left(\frac{p_{3} f}{\left(E_{2}^{*}+f\right)^{2}}-\mu_{2}\right)\left(r_{2}-\frac{a E_{2}^{*}}{g_{2}}\right)=0
\end{aligned}
$$

Equation (10) can be written as follows:

with:

$$
\lambda^{2}-x_{2} \lambda+y_{2}=0
$$

$$
\begin{gathered}
x_{2}=\frac{p_{3} f}{\left(E_{2}^{*}+f\right)^{2}}-\mu_{2}+r_{2}-\frac{a E_{2}^{*}}{g_{2}} \\
y_{2}=\left(\frac{p_{3} f}{\left(E_{2}^{*}+f\right)^{2}}-\mu_{2}\right)\left(r_{2}-\frac{a E_{2}^{*}}{g_{2}}\right)
\end{gathered}
$$

Eigen values obtained from equation (10) are

$$
\lambda_{1,2}=\frac{x_{2} \pm \sqrt{x_{2}^{2}-4 y_{2}}}{2}
$$

$y_{2}$ is the determinant of the matrix $J_{P_{2}}$ and $x_{2}$ is the trace of a matrix $J_{P_{2}}$.

a) If $y_{2}>0$ and $x_{2}^{2}-4 y_{2} \geq 0$ then the equilibrium point $P_{2}\left(E_{2}^{*}, 0\right)$ in the form of nodes, and if $x_{2}<0$ then $P_{2}\left(E_{2}^{*}, 0\right)$ is asymptotically stable. If $x_{2}>0$ then $P_{2}\left(E_{2}^{*}, 0\right)$ is unstable.

b) If $y_{2}>0, x_{2}^{2}-4 y_{2}<0$ and $x_{2} \neq 0$ then the equilibrium point $P_{2}\left(E_{2}^{*}, 0\right)$ in the form of focus, and if $x_{2}<0$ then $P_{2}\left(E_{2}^{*}, 0\right)$ is asymptotically stable. If $x_{2}>0$ then $P_{2}\left(E_{2}^{*}, 0\right)$ is unstable.

3) For the infected cancer equilibrium point $\mathrm{P}_{3}\left(\mathrm{E}_{3}^{*}, \mathrm{~T}_{2}^{*}\right)$, substitution of $\mathrm{P}_{3}\left(\mathrm{E}_{3}^{*}, \mathrm{~T}_{2}^{*}\right)$ into (6) can be used to obtain the characteristic equation as bellow:

$$
\begin{gathered}
\lambda^{2}-\left(\frac{p_{3} f}{\left(E_{3}^{*}+f\right)^{2}}-\mu_{2}+\left(1-2 b T_{2}^{*}\right) r_{2}-\frac{a g_{2} E_{3}^{*}}{\left(T_{2}^{*}+g_{2}\right)^{2}}\right) \lambda+ \\
\left(\frac{p_{3} f}{\left(E_{3}^{*}+f\right)^{2}}-\mu_{2}\right)\left(\left(1-2 b T_{2}^{*}\right) r_{2}-\frac{a g_{2} E_{3}^{*}}{\left(T_{2}^{*}+g_{2}\right)^{2}}\right)+\frac{c a T_{2}^{*}}{T_{2}^{*}+g_{2}}=0
\end{gathered}
$$




$$
\lambda^{2}-x_{3} \lambda+y_{3}=0
$$

with:

$$
\begin{gathered}
x_{3}=\left(\frac{p_{3} f}{\left(E_{3}^{*}+f\right)^{2}}-\mu_{2}+\left(1-2 b T_{2}^{*}\right) r_{2}-\frac{a g_{2} E_{3}^{*}}{\left(T_{2}^{*}+g_{2}\right)^{2}}\right) \\
y_{3}=\left(\frac{p_{3} f}{\left(E_{3}^{*}+f\right)^{2}}-\mu_{2}\right)\left(\left(1-2 b T_{2}^{*}\right) r_{2}-\frac{a g_{2} E_{3}^{*}}{\left(T_{2}^{*}+g_{2}\right)^{2}}\right)+ \\
\frac{c a T_{2}^{*}}{T_{2}^{*}+g_{2}}
\end{gathered}
$$

Eigen values obtained from Equation (12) is

$$
\lambda_{1,2}=\frac{x_{3} \pm \sqrt{x_{3}^{2}-4 y_{3}}}{2}
$$

$y_{3}$ is the determinant of the matrix $J_{P_{3}}$ and $x_{3}$ is the trace of a matrix $J_{P_{3}}$.

a) If $y_{3}>0$ and $x_{3}^{2}-4 y_{3} \geq 0$ then the equilibrium point $P_{3}\left(E_{3}^{*}, T_{2}^{*}\right)$ in the form of nodes, and if $x_{3}<0$ then $P_{3}\left(E_{3}^{*}, T_{2}^{*}\right)$ is asymptotically stable. If $x_{3}>0$ then $P_{3}\left(E_{3}^{*}, T_{2}^{*}\right)$ is unstable.

b) If $y_{3}>0, x_{3}^{2}-4 y_{3}<0$ and $x_{3} \neq 0$ then the equilibrium point $P_{3}\left(E_{3}^{*}, T_{2}^{*}\right)$ in the form of focus, and if $x_{3}<0$ then $P_{3}\left(E_{3}^{*}, T_{2}^{*}\right)$ is asymptotically stable. If $x_{3}>0$ then $P_{3}\left(E_{3}^{*}, T_{2}^{*}\right)$ is unstable.

Analog for $P_{4}, P_{5}$ and $P_{6}$ in order to obtain the eigen values of characteristic equation for $P_{4}$ is

$$
\lambda_{1,2}=\frac{x_{4} \pm \sqrt{x_{4}^{2}-4 y_{4}}}{2}
$$

$y_{4}$ is the determinant of the matrix $J_{P_{4}}$ and $x_{4}$ is the trace of a matrix $J_{P_{4}}$.

a) If $y_{4}>0$ and $x_{4}^{2}-4 y_{4} \geq 0$ then the equilibrium point $P_{4}\left(E_{4}^{*}, T_{2}^{*}\right)$ in the form of nodes, and if $x_{4}<0$ then $P_{4}\left(E_{4}^{*}, T_{2}^{*}\right)$ asymptotically stable. If $x_{4}>0$ then $P_{4}\left(E_{4}^{*}, T_{2}^{*}\right)$ unstable.

b) If $y_{4}>0, x_{4}^{2}-4 y_{4}<0$ and $x_{4} \neq 0$ then the equilibrium point $P_{4}\left(E_{4}^{*}, T_{2}^{*}\right)$ in the form of nodes focus, and if $x_{4}<0$ then $P_{4}\left(E_{4}^{*}, T_{2}^{*}\right)$ asymptotically stable. If $x_{4}>0$ then $P_{4}\left(E_{4}^{*}, T_{2}^{*}\right)$ unstable.

Eigen values of the characteristic equation for the $P_{5}$ is

$$
\lambda_{1,2}=\frac{x_{5} \pm \sqrt{x_{5}^{2}-4 y_{5}}}{2}
$$

$y_{5}$ is the determinant of the matrix $J_{P_{5}}$ and $x_{5}$ is the trace of a matrix $J_{P_{5}}$.

a) If $y_{5}>0$ and $x_{5}^{2}-4 y_{5} \geq 0$ then the equilibrium point $P_{5}\left(E_{5}^{*}, T_{3}^{*}\right)$ in the form of nodes, and if $x_{5}<0$ then $P_{5}\left(E_{5}^{*}, T_{3}^{*}\right)$ is asymptotically stable. If $x_{5}>0$ then $P_{5}\left(E_{5}^{*}, T_{3}^{*}\right)$ is unstable.

b) If $y_{5}>0, x_{5}^{2}-4 y_{5}<0$ and $x_{5} \neq 0$ then the equilibrium point $P_{5}\left(E_{5}^{*}, T_{3}^{*}\right)$ in the form of nodes focus, and if $x_{5}<0$ then $P_{5}\left(E_{5}^{*}, T_{3}^{*}\right)$ is asymptotically stable. If $x_{5}>0$ then $P_{5}\left(E_{5}^{*}, T_{3}^{*}\right)$ is unstable.

Eigen values of the characteristic equation for the $P_{6}$ is

$$
\lambda_{1,2}=\frac{x_{6} \pm \sqrt{x_{6}^{2}-4 y_{6}}}{2}
$$

$y_{6}$ is the determinant of the matrix $J_{P_{6}}$ and $x_{6}$ is the trace of a matrix $J_{P_{6}}$. a) If $y_{6}>0$ and $x_{6}^{2}-4 y_{6} \geq 0$ then the equilibrium point $P_{6}\left(E_{6}^{*}, T_{3}^{*}\right)$ in the form of nodes, and if $x_{6}<0$ then $P_{6}\left(E_{6}^{*}, T_{3}^{*}\right)$ is asymptotically stable. If $x_{6}>0$ then $P_{6}\left(E_{6}^{*}, T_{3}^{*}\right)$ is unstable.

b) If $y_{6}>0, x_{6}^{2}-4 y_{6}<0$ and $x_{6} \neq 0$ then the equilibrium point $P_{6}\left(E_{6}^{*}, T_{3}^{*}\right)$ in the form of nodes focus, and if $x_{6}<0$ then $P_{6}\left(E_{6}^{*}, T_{3}^{*}\right)$ is asymptotically stable. If $x_{6}>0$ then $P_{6}\left(E_{6}^{*}, T_{3}^{*}\right)$ is unstable.

\section{NUMERICAL SIMULATION}

Three simulations were being used to see the dynamics of effector cells and tumor cells. The initial value used in these simulations are $E(0)=T(0)=10^{3}$. Table II contained the values of the parameters for numerical simulations.

TABLE II: PARAMETER VALUES USED IN NUMERICAL SIMULATION [1]

\begin{tabular}{|l|c|c|c|c|}
\hline \multirow{2}{*}{ Simulation } & \multicolumn{4}{|c|}{ Parameter } \\
\cline { 2 - 5 } & $\mu_{2}$ & $p_{3}$ & $f$ & $s_{1}$ \\
\hline 1 & 0.03 & 0.1245 & $10^{-3}$ & 1 \\
\hline 2 & 0.03 & 0.1245 & $10^{-3}$ & 764.5072 \\
\hline 3 & 0.03 & 0.1245 & $10^{-3}$ & 100 \\
\hline
\end{tabular}

\begin{tabular}{|l|c|c|c|c|c|}
\hline \multirow{2}{*}{ Simulation } & \multicolumn{5}{|c|}{ Parameter } \\
\cline { 2 - 6 } & $c$ & $r_{2}$ & $b$ & $a$ & $g_{2}$ \\
\hline 1 & 0.05 & 0.18 & $10^{-9}$ & 1 & $10^{5}$ \\
\hline 2 & 0.3710 & 0.0023 & $10^{-9}$ & 38.004 & $10^{5}$ \\
\hline 3 & 0.05 & 0.0523 & $10^{-9}$ & 2 & $10^{5}$ \\
\hline
\end{tabular}

Based on the simulation 1, two equilibrium points $\left(P_{2}(38,0)\right.$ and $\left.P_{6}(20175,12083)\right)$ are eligible in existence. Stability of the simulation 1 is $P_{2}$ equilibrium point showed unstable result and has the type of saddle point, while $P_{6}$ is asymptotically stable and has a kind of sink focus point, which means the population of effector cells and tumor cells will grow in tandem. Based on the simulation 2, there is one point of equilibrium $\left(P_{2}(25488,0)\right)$ is eligible in existence. Stability condition of the equilibrium point $P_{2}$ in simulation 2 is asymptotically stable and has a kind of sink node point, means the effector cell population will increase while the tumor cell population will disappear with increasing of $t$. On the simulation 3 , there is one point of equilibrium that was eligible in existence $\left(P_{2}(3338,0)\right)$. Stability conditions of the equilibrium point $P_{2}$ in simulation 3 is asymptotically stable and has a kind of sink node point, the effector cell population will be constant at the equilibrium point, while the population of tumor cells will disappear with increasing of $t$. Fig. 2(a), (b), and (c) showed respectively to simulation 1, 2, and 3-point equilibrium models.

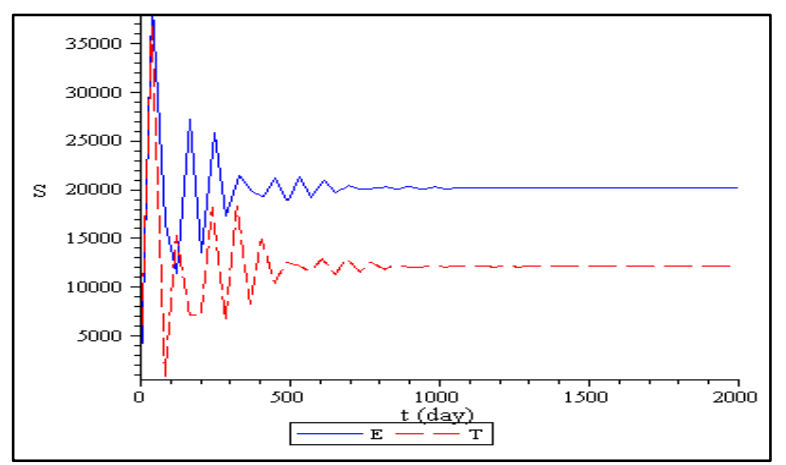

(a) 


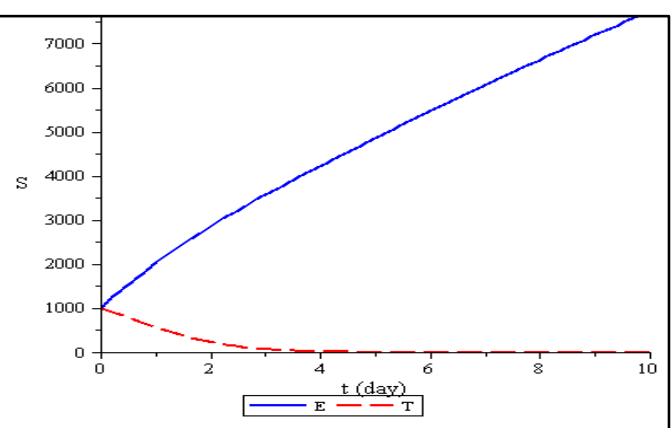

(b)

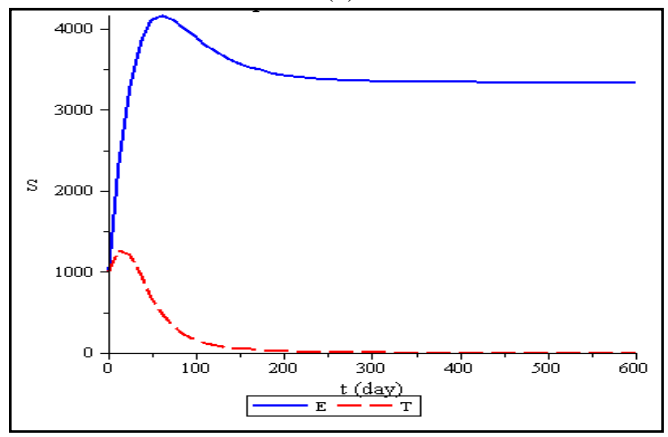

(c)

Fig. 2. Simulation models (2).

\section{CONCLUSION}

Gene therapy models developed from Lotka-Volterra models and Kirschner and Panneta models which the effector molecule is replaced by a self proliferation of cell on immune effector cells. Disease-free conditions for gene therapy models are cancer-free equilibrium conditions, $T=0$. Furthermore, the local stability of free cancer equilibrium point and cancer-infected equilibrium point have to be analyzed. With the parameter value given, the simulation model of gene therapy is done.

\section{ACKNOWLEDGMENT}

The authors wish to thank International Affairs and Partnership of Yogyakarta State University for supporting funds. The authors also wish to thank the reviewers for theirs helpful recommendations.

\section{REFERENCES}

[1] A. Tsygvintsev, S. Marino, and D. E. Kirshner, A Mathematical Model of Gene Therapy for The Treatment of Cancer, Springer-Verlag, Berlin-Heidelberg- New York, 2013.

[2] Ayahbunda. [Online] Available: http://www.ayahbunda.co.id/Artikel/keluarga/tips/mengatasi.efek.sam ping.kemoterapi/001/005/193/1/1

[3] Kabarinews. [Online]. Available: http://kabarinews.com/kesehatan-harapan-baru-pengobatan-kanker/

[4] N. L. P. I. Dharmayanti, "Study of molecular biology: Supressor gene (p53) as gene target for cancer treatment," Wartazoa, vol. 13, no. 3, 2013.

[5] T. L. Wargasetia, "Gene therapy for cancer," Journal of Public Health, vol. 4, no. 2, 2005.

[6] D. Kirschner and J. C. Panetta, "Modeling immunotherapy of the tumor-immune interaction," Journal of Mathematical Biology, vol. 37, no. 3, pp. 235-252, 1998

[7] W. Stephanie. (2009). Gene Therapy, An Innovative Approach to Cancer Treatment. [Online]. Available: http://cosmos.ucdavis.edu/archives/2009/cluster1/WRAITH_STEPH. pdf. was taken on 15 December 2013.

[8] G. J. Olsder and J. W. V. D. Woude, Mathematical Systems Theory, Netherland: VVSD, 2004.

[9] P. Lawrence, Differential Equations and Dynamical Systems, ${ }^{\text {rd }}$, New York: Springer, 2001.

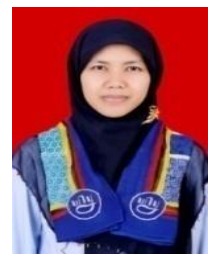

Dwi Lestari was born in Klaten, in 1985. She graduated bachelor from Yogyakarta State University in 2007 and graduated master from Gadjah Mada University in 2010. She is a lecturer at Mathematics Education Department, Mathematics and Natural Science Faculty, Yogyakarta State University, Indonesia since 2010 until now. Her research interests are in applied mathematics such as mathematical modelling especially mathematical biology.

Dwi Lestari owns was a membership of Indonesian Mathematics Society (IndoMs) since 2011.

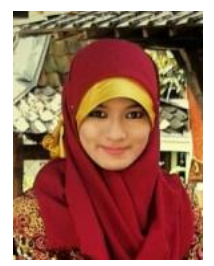

Ratnasari Dwi Ambarwati was born in Yogyakarta, in 1992. She is a fresh graduate from Yogyakarta State University in 2014. Her research interest is mathematical modelling in biology. 